\title{
Pathogenicity in six Australian reptile species following experimental inoculation with Bohle iridovirus
}

\author{
E. Ariel* , W. Wirth, G. Burgess, J. Scott, L. Owens \\ College of Public Health, Medical and Veterinary Sciences, James Cook University, Townsville, 4811 QLD, Australia
}

\begin{abstract}
Ranaviruses are able to infect multiple species of fish, amphibian and reptile, and some strains are capable of interclass transmission. These numerous potential carriers and reservoir species compound efforts to control and contain infections in cultured and wild populations, and a comprehensive knowledge of susceptible species and life stage is necessary to inform such processes. Here we report on the challenge of 6 water-associated reptiles with Bohle iridovirus (BIV) to investigate its potential pathogenicity in common native reptiles of the aquatic and riparian fauna of northern Queensland, Australia. Adult tortoises Elseya latisternum and Emydura krefftii, snakes Boiga irregularis, Dendrelaphis punctulatus and Amphiesma mairii, and yearling crocodiles Crocodylus johnstoni were exposed via intracoelomic inoculation or co-habitation with infected con-specifics, but none were adversely affected by the challenge conditions applied here. Bohle iridovirus was found to be extremely virulent in hatchling tortoises E. latisternum and $E$. krefftii via intracoelomic challenge, as demonstrated by distinct lesions in multiple organs associated with specific immunohistochemistry staining and a lethal outcome $(10 / 17)$ of the challenge. Virus was re-isolated from 2/5 E. latisternum, 4/12 E. krefftii and 1/3 brown tree snakes B. irregularis. Focal necrosis, haemorrhage and infiltration of granulocytes were frequently observed histologically in the pancreas, liver and sub-mucosa of the intestine of challenged tortoise hatchlings. Immunohistochemistry demonstrated the presence of ranavirus antigens in the necrotic lesions and in individual cells of the vascular endothelium, the connective tissue and in granulocytes associated with necrosis or present along serosal surfaces. The outcome of this study confirms hatchling tortoises are susceptible to BIV, thereby adding Australian reptiles to the host range of ranaviruses. Additionally, given that BIV was originally isolated from an amphibian, our study provides additional evidence that interclass transmission of ranavirus may occur in the wild.
\end{abstract}

KEY WORDS: Ranavirus $\cdot$ Challenge trials $\cdot$ Reptiles $\cdot$ Crocodiles $\cdot$ Tortoises $\cdot$ Snakes

\section{INTRODUCTION}

In the mid-1980s, an iridovirus-like agent was isolated from redfin perch Perca fluviatilis in epizootic mortality events in wild populations of southern Australia (Langdon et al. 1986). Koch's postulates were fulfilled via experimental challenge trials, which also proved the virus, named epizootic haematopoietic necrosis virus (EHNV), to be pathogenic to 4 other species of fish (Langdon \& Humphrey 1987). The virus was later determined to belong to the genus
Ranavirus and was listed by the World Organisation for Animal Health (OIE) as 1 of 8 viral diseases of fish (OIE 2014) due to the high pathogenicity experienced in $P$. fluviatilis and the effect in rainbow trout Oncorhynchus mykiss under wild and cultured conditions (Becker et al. 2013).

A very similar ranavirus, Bohle iridovirus (BIV), was subsequently isolated from a mortality event in ornate borrowing frogs Limnodynastes ornatus in the northern part of Australia (Hyatt et al. 2000, Speare \& Smith 1992). This isolate was pathogenic to both 
amphibians and fish under experimental conditions, which showed its potential to infect a wide range of animals (Moody \& Owens 1994, Cullen et al. 1995, Ariel \& Owens 1997). The ability of some ranaviruses to infect across ectothermic vertebrate classes was later reported in wild sympatric taxa when Mao et al. (1999) isolated a specific strain of an FV3-like virus from co-habiting frogs and fish; Currylow et al. (2014) subsequently detected ranavirus presence in sympatric larval amphibians and box turtles. In the latter study, only the major capsid protein gene fragment was sequenced, and it is therefore not possible to determine if it was exactly the same strain. Several laboratory studies have also demonstrated that interclass transmission of ranaviruses is possible (Bayley et al. 2013, Brenes et al. 2014).

Ranaviruses have progressively become prominent pathogens of fish (Ahne et al. 1989, Pozet et al. 1992, Bovo et al. 1993, Bigarré et al. 2008) and have earned ranavirus infection in amphibians a listing by the OIE (Schloegel et al. 2010) due to its strong association with mass-mortality events and cases of amphibian declines worldwide (e.g. Pearman \& Garner 2005, Ariel et al. 2009, Teacher et al. 2010, Weir et al. 2012, Price et al. 2014). In addition to infections in amphibians and fish, several publications document ranavirus as a cause of disease in reptiles (e.g. Hyatt et al. 2002, Marschang 2011, Allender et al. 2013a). The capacity of ranavirus to cross species boundaries makes for complex epidemiology with potential reservoirs in many different species in any given location. This study aims to clarify the potential pathogenicity of BIV in common native Australian reptiles of the aquatic and riparian fauna of northern Queensland, where BIV was originally isolated.

\section{MATERIALS AND METHODS}

\section{Virus}

The original amphibian isolate of BIV was propagated in bluegill fry (BF-2) cells (Wolf et al. 1966), grown in Dulbecco's modified Eagle's medium supplemented with $5 \%$ foetal bovine serum and $5 \%$ bovine donor serum. Antibiotics (benzylpenicillin, streptomycin, polymycin B and kanamycin) and fungicide (Fungizone) were added at $1 \%$. The BF-2 cultures were incubated at $26^{\circ} \mathrm{C}$. The virus was harvested at complete cytopathic effect, frozen at $-20^{\circ} \mathrm{C}$, thawed 3 times and stored at $-70^{\circ} \mathrm{C}$. Negative controls consisted of uninfected cell cultures treated in the same manner.

\section{Animals}

Individuals of 6 species of reptile were collected from the wild in northern Queensland under permit (Scientific Purposes Permit No. H0/000096/95/SAA) from the Queensland Department of Environment and Resource Management (DERM), which also included their offspring or animals donated from farmed stock (Table 1). The animals were kept at approximately $25^{\circ} \mathrm{C}$ at the experimental facilities at the School of Veterinary and Biomedical Sciences, James Cook University. All animal experiments were covered by permit from the Experimental Animals Ethics Committee, James Cook University (Ethics Approval No. A302). Animals were humanely euthanased with an overdose of pentabarbitol (Lethabarb, $2 \mathrm{ml} \mathrm{kg}{ }^{-1}$ body weight).

\section{Tortoises}

Adults and 1-wk-old hatchlings of Emydura krefftii and Elseya latisternum were investigated in the challenge studies, which ran for $4 \mathrm{wk}$. Prior to the investigation, female tortoises with hard-shelled eggs were induced with oxytocin (10 international units $\mathrm{ml}^{-1}$ ) (Heriot AgVet) to lay eggs in shallow water according to recommendations by Ewert \& Leggler (1978). Eggs were incubated in sterile vermiculite in humid atmosphere incubators at $30^{\circ} \mathrm{C}$ for approximately $70 \mathrm{~d}$.

Adults were ranked according to weight and assigned randomly within a weight class to 1 of 3 treatments: inoculations with $500 \mu \mathrm{l}$ BIV $\left(10^{4.5} \mathrm{TCID}_{50}\right.$ $\mathrm{ml}^{-1}$ ) intracoelomic (ic); co-habitation (placebo inoculation with phosphate buffered saline [PBS]) ic; and negative control (placebo as for the co-habitation animals) (Table 1). The co-habitation group was housed with BIV-inoculated animals in the Aquatic Animal Infection Facility, as were all BIV-exposed animals, and the control group in the quarantine area. Adult tortoises were kept in glass tanks $(40 \times 60$ $\times 90 \mathrm{~cm}$ ) filled with tap water to a depth of $15 \mathrm{~cm}$ and a platform for basking. The tortoises were fed a diet of diced beef and freshly chopped tomatoes 3 times weekly. A complete water change was carried out on days subsequent to feeding.

Eight E. latisternum eggs were successfully hatched. Five hatchlings were inoculated with $50 \mu \mathrm{l}$ $\operatorname{BIV}\left(10^{3} \mathrm{TCID}_{50} \mathrm{ml}^{-1}\right)$ ic, while the other 3 received equal volumes of PBS. Twelve E. krefftii hatchlings were inoculated with BIV as described above and another 12 with PBS. Hatchlings were maintained 
Table 1. Number of animals in the different challenge treatments with reference to species, origin, tagging method, weight and challenge route. Inoc: inoculation; co-hab: co-habitation; neg: negative control

\begin{tabular}{|c|c|c|c|c|c|}
\hline Species & Origin & $\begin{array}{l}\text { Tagging } \\
\text { method }\end{array}$ & $\begin{array}{l}\text { Weight } \\
\text { (g) }\end{array}$ & $\begin{array}{l}\text { Challenge } \\
\text { route }\end{array}$ & $\begin{array}{l}\text { No. animals } \\
\text { in trial }\end{array}$ \\
\hline \multirow{5}{*}{$\begin{array}{l}\text { Krefft's river tortoise } \\
\text { Emydura krefftii }\end{array}$} & \multirow[t]{3}{*}{ Townsville waterways } & \multirow[t]{3}{*}{ Shell notching } & \multirow[t]{3}{*}{$408-2146$} & Inoc & 6 \\
\hline & & & & Co-hab & 5 \\
\hline & & & & Neg & 6 \\
\hline & \multirow[t]{2}{*}{ Hatched in captivity } & \multirow[t]{2}{*}{ Nail polish } & \multirow[t]{2}{*}{$6-8$} & Inoc & 12 \\
\hline & & & & Neg & 12 \\
\hline \multirow{5}{*}{$\begin{array}{l}\text { Saw-shelled tortoise } \\
\text { Elseya latisternum }\end{array}$} & \multirow{3}{*}{ Mt. Surprise waterways } & \multirow{3}{*}{ Shell notching } & \multirow{3}{*}{$112-2395$} & Inoc & 5 \\
\hline & & & & Co-hab & 5 \\
\hline & & & & Neg & 6 \\
\hline & \multirow[t]{2}{*}{ Hatched in captivity } & \multirow[t]{2}{*}{ Nail polish } & \multirow[t]{2}{*}{$6-8$} & Inoc & 5 \\
\hline & & & & Neg & 3 \\
\hline \multirow{3}{*}{$\begin{array}{l}\text { Freshwater crocodile } \\
\text { Crocodylus johnstoni }\end{array}$} & \multirow[t]{3}{*}{ Donated from farm } & \multirow[t]{3}{*}{ Removal of tail scutes } & \multirow[t]{3}{*}{$165-427$} & Inoc & 5 \\
\hline & & & & Co-hab & 5 \\
\hline & & & & Neg & 6 \\
\hline \multirow{3}{*}{$\begin{array}{l}\text { Keelback snake } \\
\text { Amphiesma mairii }\end{array}$} & \multirow[t]{3}{*}{ Giru } & \multirow[t]{3}{*}{ Scale clipping } & \multirow[t]{3}{*}{$44-153$} & Inoc & 2 \\
\hline & & & & Co-hab & 2 \\
\hline & & & & Neg & 2 \\
\hline \multirow{3}{*}{$\begin{array}{l}\text { Green tree snake } \\
\text { Dendrelaphis punctulatu }\end{array}$} & \multirow{3}{*}{$\begin{array}{l}\text { Townsville relocation } \\
\text { us program }\end{array}$} & \multirow[t]{3}{*}{ Scale clipping } & \multirow[t]{3}{*}{$42-314$} & Inoc & 2 \\
\hline & & & & Co-hab & 1 \\
\hline & & & & Neg & 2 \\
\hline \multirow{3}{*}{$\begin{array}{l}\text { Brown tree snake } \\
\text { Boiga irregularis }\end{array}$} & \multirow{3}{*}{$\begin{array}{c}\text { Townsville relocation } \\
\text { program }\end{array}$} & \multirow[t]{3}{*}{ Scale clipping } & \multirow[t]{3}{*}{$187-449$} & Inoc & 3 \\
\hline & & & & Co-hab & 2 \\
\hline & & & & Neg & 2 \\
\hline
\end{tabular}

in plastic containers with $500 \mathrm{ml}$ tap water changed daily. The containers were tilted to create a dry area and a wet area for the hatchlings. The hatchlings were fed on Reptile TEN pellets (Wardley) and finely chopped tomatoes 3 times weekly. Moribund hatchlings were inappetent and did not retract head and limbs when disturbed. These were euthanased as the trial progressed for ethical reasons. Whenever an infected hatchling died or became moribund, a control animal was sacrificed to provide an equivalent ontogenic reference for histological purposes.

\section{Crocodiles}

Sixteen yearling Crocodylus johnstoni from Hartley's Creek Crocodile Farm were individually marked by removing tail scutes according to the crocodile marking code described by DERM (Anonymous 1995). Crocodiles were ranked according to weight, allocated to 1 of 3 treatments as described for tortoises (Table 1) and housed in $1000 \mathrm{l}$ polypropylene bins (RELNTM). The crocodiles were fed a diet consisting of a blended mixture of $75 \%$ kangaroo meat and $25 \%$ chicken heads 4 times weekly.

\section{Snakes}

Boiga irregularis and Dendrelaphis punctulatus were kindly made available through the DERM snake relocation program for Townsville. Amphiesma mairii were caught near Giru, $40 \mathrm{~km}$ south of Townsville. Snakes were individually marked by scale clipping according to Fitch (1987). Within each species, snakes were ranked according to weight and allocated to 1 of 3 treatments as described for tortoises (Table 1). Snakes were housed in pairs or in groups of 3 in polystyrene boxes $(35 \times 60 \times 20 \mathrm{~cm})$, which were placed on bricks in 10 -cm-deep water in RELNTM bins to prevent ants from entering the boxes and harassing the snakes. Pens were cleaned daily and snakes had access to water at all times.

\section{Viral isolation}

Samples from selected organs (liver, kidney, spleen, heart, brain, muscle, lung, gonad, pancreas, stomach and small intestine) of adult tortoises, crocodiles and snakes, and from the liver of hatchling tortoises, were homogenized with $1 \mathrm{ml}$ distilled water and subjected to 3 freeze/thaw cycles at 
$-20^{\circ} \mathrm{C}$ before clarification by centrifugation (Beckman microfuge E) at $20600 \times g$ for $15 \mathrm{~min}$ at $4^{\circ} \mathrm{C}$. A total of $50 \mu \mathrm{l}$ supernatant from each tube was added to $80 \%$ confluent monolayers of BF-2 cells in duplicate wells of a 24-well tissue culture plate. The plates were incubated in a humid, $5 \% \mathrm{CO}_{2}$ rich atmosphere at $26^{\circ} \mathrm{C}$ for $1 \mathrm{wk}$ and checked for wet cytopathic effect (CPE) daily. For each sample, 2 blind passages were performed at weekly intervals, by transferring $50 \mu \mathrm{l}$ cell culture supernatant from inoculated wells to corresponding wells with new, non-infected BF-2 cell monolayers on a separate plate.

\section{Bacteriology}

Swabs were collected from the kidney and liver of adult tortoises, snakes and crocodiles. Samples were cultured on blood agar and MacConkey at 28 and $37^{\circ} \mathrm{C}$.

\section{Histology}

Dead animals were necropsied immediately on discovery or after euthanasia. Any observable lesions, as well as a range of tissues (liver, lung, large intestine, kidney, spleen, pancreas, muscle, heart, thymus, thyroid and yolk, when present) were preserved in $10 \%$ neutral buffered formaldehyde. Owing to the small size of the hatchlings, the entire viscera of each individual was mounted in a paraffin block and subsequently sectioned. The organs present in a section were dependent on its orientation and level, hence not all organs were available for each animal. Trimmed tissues were processed and embedded in paraffin wax. Sections were cut at a thickness of $5 \mu \mathrm{m}$, stained with haematoxylin and eosin, and mounted using routine methods (Bancroft \& Gamble 2008).

\section{Immunohistochemistry}

Sections of $5 \mu \mathrm{m}$ were cut from paraffin-embedded samples of turtle organs, placed on positively charged slides and taken to water via xylene and ethanol. Sections were boiled in TE buffer $(\mathrm{pH} 8.5)$ for 20 min using an $850 \mathrm{~W}$ microwave, washed with tap water and dried. The procedure was carried out at room temperature and the sections were washed 3 times with TE between each subsequent procedure.
Sections were blocked with ELISA buffer (containing casein) for $30 \mathrm{~min}$, then $50 \mu \mathrm{l}$ rabbit anti-EHNV antibody (1:1500) (Steiner et al. 1991) was added to each slide and incubated for $1.5 \mathrm{~h}$. Slides were then incubated in a solution of $0.3 \%$ hydrogen peroxide and $0.1 \%$ sodium azide in TE for $15 \mathrm{~min}$ to inactivate endogenous peroxidases, and washed, before adding $50 \mu \mathrm{l}$ goat anti-rabbit horseradish peroxidase conjugate antibody diluted in TE with $1 \%$ BSA to each slide and incubating for $1.5 \mathrm{~h}$. Following this, the sections were developed with the addition of $100 \mu \mathrm{l}$ of the chromogenic solution $(0.005 \%$ 3-amino-9-ethylcarbazole and $0.001 \%$ hydrogen peroxide in substrate buffer) for $20 \mathrm{~min}$. Finally, the slides were counterstained with haematoxylin, blued with Scott's tap water substitute, mounted with Aquatex (Merck Cat. No. 1.08562.0050) and examined under a light microscope. Viral antigen in infected cells stained red-brown. Controls for non-specific binding and endogenous peroxidase were produced by following the above method without adding the primary and secondary antibodies, respectively.

\section{RESULTS}

\section{Mortality}

Of the BIV-inoculated Elseya latisternum hatchlings, 3 died during the experiment: 2 died on Day 10 post inoculation (pi) and 1 on Day 20 pi. Two were moribund and subsequently euthanised on Day 20 pi. Of the 12 Emydura krefftii hatchlings, 5 died during the experiment on Days 16, 22, 24, 25 and 29 pi, 4 were euthanised as part of scheduled collection on Days 4, 8, 11 and $29 \mathrm{pi}$, and the remainder were euthanased because they were found moribund on Days 18, 24 and 29 pi. Tortoises appeared lively and eating well right up to the day before they became moribund or were discovered dead in their pen. None of the hatchling tortoises of the control group, nor any of the adult tortoises, crocodiles and 3 species of snake died during the experimental trials.

\section{Viral and bacterial isolation}

Virus was isolated from 2 of the 5 dead E. latisternum hatchlings and from 4 of the E. krefftii hatchlings: 3 of the 5 dead hatchlings and 1 live, which was sampled on Day 8 pi. The isolates caused cytopathic effects indicative of BIV in the cell culture. No virus was isolated from the adult tortoises or the crocodiles 
Table 2. Number of Emydura krefftii hatchings in each treatment (BIV inoculated and negative control) with specific necrotic lesions consisting of necrosis and inflammation, versus number of animals examined for each organ. na: not applicable

\begin{tabular}{|c|c|c|c|c|c|c|c|c|c|c|c|}
\hline & Liver & Lung & Large intestine & Kidney & Spleen & Pancreas & Muscle & Heart & Thymus & Thyroid & Yolk \\
\hline BIV inoculated & $7 / 9$ & $0 / 8$ & $3 / 8$ & $2 / 3$ & $1 / 2$ & $1 / 2$ & $1 / 6$ & $0 / 4$ & $0 / 2$ & na & $0 / 4$ \\
\hline Negative control & $0 / 8$ & $0 / 8$ & $0 / 7$ & $0 / 3$ & $0 / 2$ & $0 / 5$ & $0 / 4$ & $0 / 4$ & $0 / 4$ & $0 / 1$ & $0 / 3$ \\
\hline
\end{tabular}

in the experiments. BIV was isolated from the liver of an inoculated Boiga irregularis at $4 \mathrm{wk}$ pi, but not from any other snakes. Bacteria were not isolated from kidney or liver samples from any of the animals during necropsy.

\section{Histopathology}

Distinct necrotic lesions with inflammation occurred in organs of 10 infected E. krefftii hatchlings examined (Table 2), but not in uninfected animals. Lesions were often perivascular or adjacent to blood vessels, with multifocal necrosis consisting of karyorrhexis of granulocytes, endothelial and adjacent cells, haemorrhage, infiltration of granulocytes and, rarely, perivascular fibrin deposition. These lesions were prominent in the pancreas (Fig. 1A), liver (Fig. 1B) and sub-mucosa of the large intestine, but individual animals also had lesions in the kidney, spleen and muscle (Table 2). Fibrinoid vasculitis and thrombosis as reported in other ranavirus infections of freshwater turtles (De Voe et al. 2004, Johnson et al. 2007, 2008, Allender et al. 2013a) were not observed in this study.

There were no differences in lesions between $E$. krefftii hatchlings that died during the challenge trials $(n=5)$ and those that were euthanased $(n=7)$. However, it was impossible to distinguish between viral lesions and post-mortem changes in 2 of the $E$. krefftii hatchlings and all 5 of the E. latisternum hatchlings, despite 2 of the latter being necropsied immediately on death. There were no specific lesions limited to the experimentally infected or co-habitation group of adult tortoises, the crocodile yearlings, or the snakes, which could be ascribed to BIV infection. Several parasites were encountered in the wildcaught snakes and turtles during post-mortem and histological examination. Live parasites in the lungs of green tree snakes were identified as Waddycephalus punctulatus (Riley \& Self 1981), while sections of parasites in internal organs were not identified, but could possibly have been tapeworms. Nematodes and trematodes were frequently found in the stomach, small intestine and large intestine of adult tur- tles. None of these parasites appeared to have caused extensive tissue damage and no other disease conditions seemed to influence the experiments.

\section{Immunohistochemistry}

Immunohistochemical staining specific to ranavirus antigens was observed in tissues from E. krefftii hatchlings exposed to BIV. Staining was observed in connective tissue, mesothelial cells, endothelial cells of veins, granulocytes and as generalized staining in necrotic areas adjacent to blood vessels (Fig. 1C,D). Non-specific staining was negligible in the antibody and conjugate internal controls (Fig. 1E).

\section{DISCUSSION}

Challenge trials with BIV have previously been carried out in frogs and fish (Ariel \& Owens 1997, Cullen \& Owens 2002, Becker et al. 2013) but this is the first challenge described for Australian reptiles. The animals in this study were chosen based on their association with freshwater, either through a semiaquatic habitat or via aquatic or semi-aquatic prey, because they were considered to be at greatest risk of encountering BIV under natural conditions. Snakes, crocodiles and adult tortoises appeared refractory to infection under the conditions tested here, whereas 10 out of 17 juvenile tortoises challenged intracoelomically died within $20 \mathrm{~d}$ of exposure.

The clinical signs associated with moribund tortoises were non-specific other than lack of appetite and lethargy. These signs are very limited compared to those described in the literature for ranavirusinfected tortoises, which include nasal and ocular discharge, oral plaques, conjunctivitis, abnormal behaviour, swelling, erythema, diarrhoea and lethargy (De Voe et al. 2004, Johnson et al. 2007, 2008, Allender et al. 2011, 2013a, Marschang 2011, Allender 2012). The pathogenicity of BIV in juvenile tortoises was rapid in the final stage and caused death within $24 \mathrm{~h}$ of the first signs of lethargy. Necropsy on 2 Elseya latisternum hatchlings was carried out imme- 

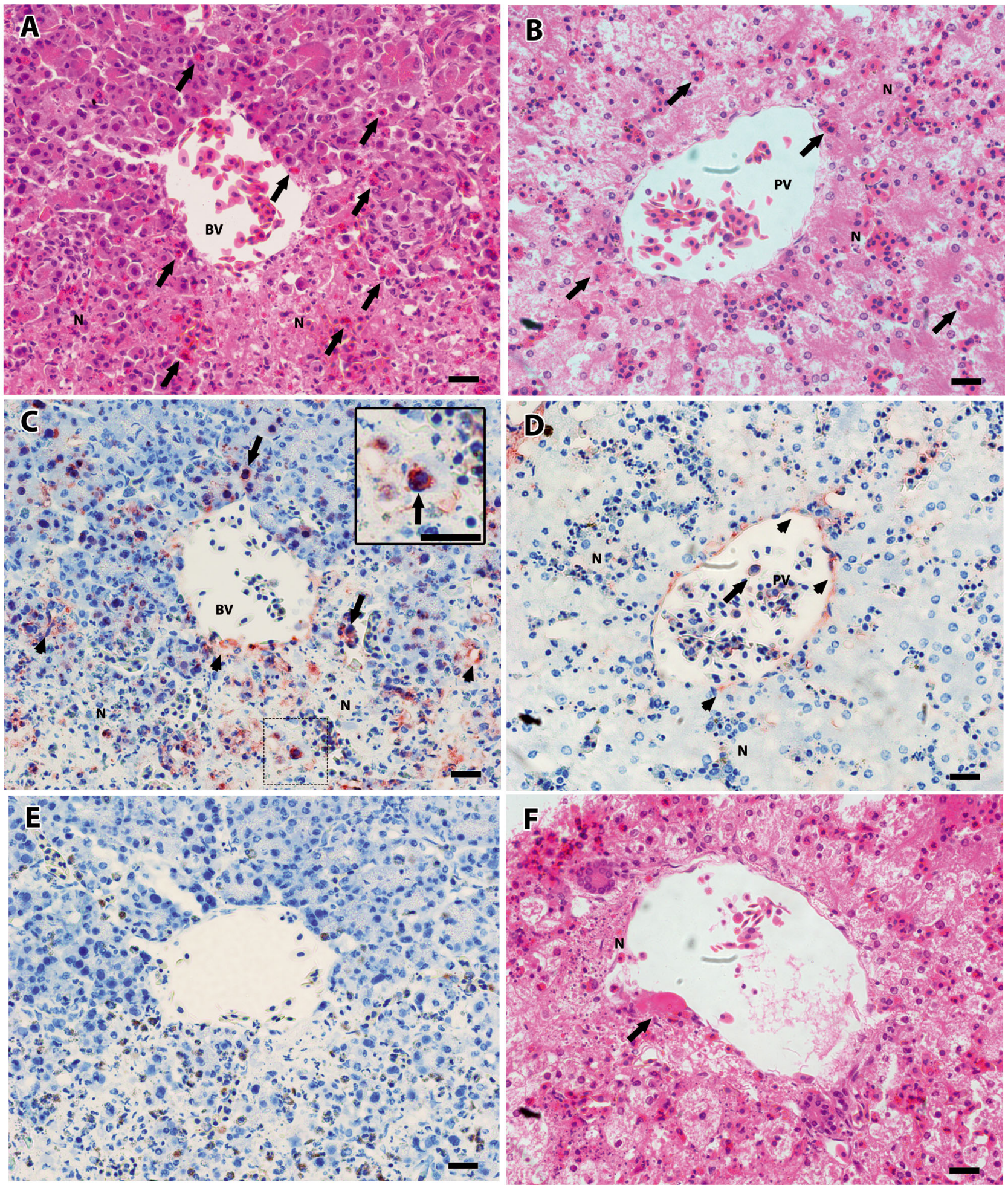

Fig. 1. Histological sections of $(\mathrm{A}, \mathrm{C}, \mathrm{E})$ pancreas and $(\mathrm{B}, \mathrm{D}, \mathrm{F})$ liver from BIV-exposed Emydura krefftii hatchlings and negative controls, stained with either haematoxylin and eosin (H\&E) or immunohistochemical staining specific to ranavirus antigens (IHC). (A) Pancreas granulocytes (long arrows) associated with necrotic lesion (N) adjacent to blood vessel (BV). H\&E. (B) Liver granulocytes (long arrows) associated with necrosis in sinusoids leading into the central vein (PV). H\&E. (C) Pancreas showing staining of granulocytes (long arrows and inset) and endothelial cells (short arrows) of the blood vessel (BV) and generalized staining in the necrotic areas (inset). IHC. (D) Liver showing staining of endothelial cells (short arrows), granulocytes (long arrows) and generalized staining in the necrotic areas of sinusoids. IHC. (E) Pancreas negative control. IHC. (F) Liver showing perivascular fibrin deposition (long arrow) adjacent to necrotic area. H\&E. Scale bars $=20 \mu \mathrm{m}$ 
diately upon death, but the organs were already autolyzed and resembled post-mortem changes for at least 2 tortoises.

Histopathological lesions consisted of multifocal necrosis in multiple organs, often centered around blood vessels, with a prominent involvement of endothelial cells and the sub-mucosa of the gastrointestinal tract. The immunohistochemical staining confirmed the presence of ranavirus antigen associated with these lesions. The immunohistochemistry technique has previously been used to demonstrate ranavirus infection in a variety of species of fish, amphibian and reptile (Hyatt et al. 2002, Cunningham et al. 2008, Balseiro et al. 2009, Cinkova et al. 2010, Becker et al. 2013), and enables an indisputable connection to be established between necrosis and the virus. Owing to cross-reactivity of polyclonal antisera between the different ranaviral strains, it is possible to utilise sera produced against one strain to identify other similar strains (Ariel et al. 2009). In this case, rabbit anti-EHNV sera bound to BIV antigens in infected tissues.

The predilection for vascular endothelial cells may indicate viraemia preceding systemic infection similar to that described for EHNV infections in redfin perch Perca fluviatilis and rainbow trout Oncorhynchus mykiss (Reddacliff \& Whittington 1996). Lesions observed here and subsequent death of the animal could be due to direct destruction of cells by the viral replication, or possibly indirect destruction by the encoded tetanus-like toxin (Eaton et al. 2007), which may act at the cellular level. The high ratio of re-isolation from affected animals possibly indicates that viral replication was taking place during the disease process and this could give rise to hostmediated damage such as cytokine storm or apoptosis (Chinchar et al. 2003).

Cytoplasmic inclusions, as described for rainbow trout and redfin perch infected with EHNV (Reddacliff \& Whittington 1996) and in infected tissues of gopher turtles, Hermann's tortoises and eastern box tortoises (Heldstab \& Bestetti 1982, Westhouse et al. 1996, Marschang et al. 1999, Allender et al. 2006), were observed in neither the BIV-exposed tortoises in this study nor the ranavirus challenge study of tortoises described by Johnson et al. (2007) or the natural infection case described by De Voe et al. (2004). However, intracytoplasmic inclusions were reported as rare events in many different organs by Johnson et al. $(2007,2008)$.

Understanding transmission dynamics at a population level is extremely important in order to comprehend and predict the epidemiology of ranavirus
(Brunner et al. 2007). Several methods of ranaviral transmission have been demonstrated experimentally for a number of trial species. These include direct exposure to cultivated virus via bath challenge, oral inoculation, intramuscular injection and intracoelemic injection, as well as host-to-host transmission via direct contact or co-habitation with infected individuals (Cullen \& Owens 2002, Johnson et al. 2007, 2008, Hoverman et al. 2010, Bayley et al. 2013, Brenes et al. 2014). Although mortality rates varied between different exposure methods, it seems they are all effective in establishing an infection. Some of these transmission routes may be artificial and by circumventing barriers to natural infection, therefore not reflect transmission in wild populations.

Infection described here was not via a natural route and perhaps the high titre of the virus was also instrumental in the fast disease process by infecting multiple organs at once and overwhelming the immune system. Had the dose been smaller and route of transmission via food or physical contact through broken skin, establishment of infection may have been slower and the immune response more efficient. Although adult tortoises received a relatively smaller dose of virus per unit bodyweight than juveniles they are likely to have a more mature immune system, or to have been previously exposed in the wild, either of which would contribute in favour of the host, rather than the virus. This was not the case in the studies described by Johnson et al. (2007, 2008) or Allender et al. (2013b), who challenged adult turtles intramuscularly with ranavirus and showed them to be susceptible, with distinct clinical signs and pathological lesions.

Pathogenicity of the infection is also assumed to be a factor of temperature as described previously for ranavirus infection in fish (Reddacliff \& Whittington 1996, Ariel et al. 2009), reptiles (Allender et al. 2013b) and amphibians (Bollinger et al. 1999, Rojas et al. 2005, Bayley et al. 2013). An increase or decrease in temperature may therefore change the pathogenicity of BIV in any of the animals tested.

Bohle iridovirus is extremely virulent in hatchling tortoises under the challenge conditions applied, as demonstrated by the distinct lesions, associated ranavirus-specific immunohistochemical staining and a lethal outcome, whereas adult tortoises, snakes and yearling crocodiles were not adversely affected in the short term. In fish, frogs and salamanders it appears the susceptibility of juveniles to BIV is higher than in more mature animals (Cullen et al. 1995, Ariel \& Owens 1997, Jancovich et al. 1997), which was paral- 
leled by the tortoises herein. Given that there was such a difference between adults and juvenile tortoises, there is no guarantee that the same pattern would not repeat itself with crocodiles and snakes; i.e. perhaps their young are also susceptible (Hyatt et al. 2002).

Pathological lesions in ranaviral infected turtles in North America by challenge or natural routes are consistently reported to include fibrinoid vasculitis and thrombosis, neither of which were observed in this study (Johnson et al. 2007, 2008, Allender et al. 2013b). Necrotic lesions were, however, often located adjacent to veins or sinusoids and association of these lesions to ranavirus was confirmed by the immunohistochemistry technique.

Given such a short disease progression and an extremely high cumulative mortality in hatchlings, it is doubtful whether serological surveys would detect immune animals among juveniles. The maturity of the immune system may play a role, as adults are refractory to infection and were able to neutralise viable virions to the extent that no virus could be isolated from any of them after $28 \mathrm{~d}$. Given that the adults used in this study were wild caught, they may previously have been exposed to ranavirus and developed protective immunity. Although the adaptive immune response of turtles is poorly understood, mature animals would be a more reasonable target for serological surveys, assuming that a ranaviral infection can cause an elevated and lasting increase in specific immunoglobulin (Ig) Y, which is thought to be the equivalent to mammalian IgG (Meddings et al. 2014).

The brown tree snakes inoculated with BIV stayed alive and asymptomatic for the $30 \mathrm{~d}$ of the trial. There was no direct indication of a ranaviral infection in the histopathological investigations, but BIV was successfully isolated from organs of 1 out of 3 snakes, indicating that the snake could be an asymptomatic carrier. Similar carrier states have been described for Xenopus frogs, where transcriptionally inactive frog virus 3 (FV3) genomic DNA can be detected in frog peritoneal leukocytes $3 \mathrm{wk}$ post infection, even after the infection has been cleared from the kidneys, the main site of infection. This suggests that peritoneal leukocytes harbor quiescent, asymptomatic FV3 despite their role in anti-FV3 immune responses (Robert 2010, Chen \& Robert 2011). Amphibians, fish and reptiles have all been identified as potential reservoirs for ranaviral infection. The ramifications for biosecurity are that absence of clinical symptoms in any of these animals is not sufficient to rule out ranaviral infection and transmission.
The Australian freshwater ecosystem is under threat from human impacts such as land degradation, pollution with fertilisers and biocides from adjacent agricultural pastures, dams and introduction of exotic species (Arthington et al. 2010, Barrett et al. 2014, Bond et al. 2014). However, the impact of disease on the survival of native fauna could have an equally detrimental influence, especially if anthropogenic stressors work in synergy to reduce the immune functions of the animals in question (Gray et al. 2009, Robert 2010). A pathogen like BIV, which can infect both fish and amphibians, is clearly suited to an opportunistic existence in a dynamic freshwater ecosystem. This study demonstrated that Australian tortoises are susceptible to BIV, thereby adding Australian reptiles to the already broad host range of this virus.

Acknowledgements. We gratefully acknowledge J. Miller, G. Hutchinson and P. Ladds for scientific advice; A. and P. Freeman from Hartley's Creek Crocodile Farm, for donation of crocodile hatchlings; I. Bell and M. Hero for help with catching keelback snakes; and anonymous reviewers for useful suggestions. The study was supported by an Australian Postgraduate Research Award. Polyclonal rabbit anti-EHNV antibody was kindly provided by Professor R. Whittington, University of Sydney, Australia.

\section{LITERATURE CITED}

Ahne W, Schlotfeldt HJ, Thomsen I (1989) Fish viruses: isolation of an icosahedral cytoplasmic deoxyribovirus from sheatfish (Silurus glanis). Zentbl Vetmed B 36:333-336

Allender MC (2012) Characterizing the epidemiology of ranavirus in North American chelonians: diagnosis, surveillance, pathogenesis, and treatment. $\mathrm{PhD}$ dissertation, University of Illinois at Urbana-Champaign, Champaign, IL

Allender MC, Fry MM, Irizarry AR, Craig L, Johnson AJ, Jones M (2006) Intracytoplasmic inclusions in circulating leukocytes from an eastern box turtle (Terrapene carolina carolina) with iridoviral infection. J Wildl Dis 42: $677-684$

Allender MC, Abd-Eldaim M, Schumacher J, McRuer D, Christian L, Kennedy M (2011) PCR prevalence of ranavirus in free-ranging eastern box turtles (Terrapene carolina carolina) at rehabilitation centers in three southeastern US states. J Wildl Dis 47:759-764

Allender MC, Mitchell MA, Mcruer D, Christian S, Byrd J (2013a) Prevalence, clinical signs, and natural history characteristics of frog virus 3-like infections in eastern box turtles (Terrapene carolina carolina). Herpetol Conserv Biol 8:308-320

Allender MC, Mitchell MA, Torres T, Sekowska J, Driskell EA (2013b) Pathogenicity of frog virus 3-like virus in red-eared slider turtles (Trachemys scripta elegans) at two environmental temperatures. J Comp Pathol 149: 356-367

Anonymous (1995) Conservation and management of Crocodylus porosus in Queensland 1995-1997. Department of Environment and Heritage, Brisbane 
Ariel E, Owens L (1997) Epizootic mortalities in tilapia Oreochromis mossambicus. Dis Aquat Org 29:1-6

- Ariel E, Nicolajsen N, Christophersen MB, Holopainen R, Tapiovaara H, Bang Jensen B (2009) Propagation and isolation of ranaviruses in cell culture. Aquaculture 294: 159-164

Arthington ÁH, Naiman RJ, Mcclain ME, Nilsson C (2010) Preserving the biodiversity and ecological services of rivers: new challenges and research opportunities. Freshw Biol 55:1-16

Balseiro A, Dalton KP, del Cerro A, Marquez I and others (2009) Pathology, isolation and molecular characterisation of a ranavirus from the common midwife toad Alytes obstetricans on the Iberian Peninsula. Dis Aquat Org 84: 95-104

Bancroft JD, Gamble M (2008) Theory and practice of histological techniques, 6th edn. Elsevier Health Sciences, London

> Barrett J, Bamford H, Jackson P (2014) Management of alien fishes in the Murray Darling Basin. Ecol Manag Restor 15:51-56

Bayley AE, Hill BJ, Feist SW (2013) Susceptibility of the European common frog Rana temporaria to a panel of ranavirus isolates from fish and amphibian hosts. Dis Aquat Org 103:171-183

Becker JA, Tweedie A, Gilligan D, Asmus M, Whittington RJ (2013) Experimental infection of Australian freshwater fish with epizootic haematopoietic necrosis virus (EHNV). J Aquat Anim Health 25:66-76

Bigarré L, Cabon J, Baud M, Pozet F, Castric J (2008) Ranaviruses associated with high mortalities in catfish in France. Bull Eur Assoc Fish Pathol 28:163-168

> Bollinger TK, Mao J, Schock D, Brigham RM, Chinchar VG (1999) Pathology, isolation, and preliminary molecular characterization of a novel iridovirus from tiger salamanders in Saskatchewan. J Wildl Dis 35:413-429

Bond N, Costelloe J, King A, Warfe D, Reich P, Balcombe S (2014) Ecological risks and opportunities from engineered artificial flooding as a means of achieving environmental flow objectives. Front Ecol Environ 12: 386-394

Bovo G, Comuzi M, DeMas S, Ceschia G, Giorgetti G, Giacometti P, Cappellozza E (1993) Isolamento di un agente virale irido-like da pesce gatto (Ictalurus melas) dallevamento. Boll Soc Ital Patol Ittica 11:3-10

> Brenes R, Miller DL, Waltzek TB, Wilkes RP and others (2014) Susceptibility of fish and turtles to three ranaviruses isolated from different ectothermic vertebrate classes. J Aquat Anim Health 26:118-126

- Brunner JL, Schock DM, Collins JP (2007) Transmission dynamics of the amphibian ranavirus Ambystoma tigrinum virus. Dis Aquat Org 77:87-95

> Chen G, Robert J (2011) Antiviral immunity in amphibians. Viruses 3:2065-2086

> Chinchar VG, Bryan L, Wang J, Long S, Chinchar GD (2003) Induction of apoptosis in frog virus 3-infected cells. Virology 306:303-312

> Cinkova K, Reschova S, Kulich P, Vesely T (2010) Evaluation of a polyclonal antibody for the detection and identification of ranaviruses from freshwater fish and amphibians. Dis Aquat Org 89:191-198

Cullen BR, Owens L (2002) Experimental challenge and clinical cases of Bohle iridovirus (BIV) in native Australian anurans. Dis Aquat Org 49:83-92

Cullen BR, Owens L, Whittington RJ (1995) Experimental infection of Australian anurans (Limnodynastes terraereginae and Litoria latopalmata) with Bohle iridovirus. Dis Aquat Org 23:83-92

Cunningham AA, Tems CA, Russell PH (2008) Immunohistochemical demonstration of ranavirus antigen in the tissues of infected frogs (Rana temporaria) with systemic haemorrhagic or cutaneous ulcerative disease. J Comp Pathol 138:3-11

> Currylow AF, Johnson AJ, Williams RN (2014) Evidence of ranavirus infections among sympatric larval amphibians and box turtles. J Herpetol 48:117-121

> De Voe R, Geissler K, Elmore S, Rotstein D, Lewbart G, Guy J (2004) Ranavirus-associated morbidity and mortality in a group of captive Eastern box turtles (Terrapene carolina carolina). J Zoo Wildl Med 35:534-543

Eaton HE, Metcalf J, Penny E, Tcherepanov V, Upton C, Brunetti CR (2007) Comparative genomic analysis of the family Iridoviridae: re-annotating and defining the core set of iridovirus genes. Virol J 4:11

Ewert MA, Legler JM (1978). Hormonal induction of oviposition in turtles. Herpetologica 34:314-318

Fitch HS (1987) Collecting and life-history techniques. In: Seigel RA, Collins JT, Novak SS (eds) Snakes: ecology and evolutionary biology. Macmillan Publishing Company, Toronto, p 143-164

Gray MJ, Miller DL, Hoverman JT (2009) Ecology and pathology of amphibian ranaviruses. Dis Aquat Org 87: 243-266

Heldstab A, Bestetti G (1982) Spontaneous viral hepatitis in a spur-tailed Mediterranean land tortoise (Testudo hermanni). J Zoo Wildl Med 13:113-120

> Hoverman JT, Gray MJ, Miller DL (2010) Anuran susceptibilities to ranaviruses: role of species identity, exposure route, and a novel virus isolate. Dis Aquat Org 89:97-107

> Hyatt AD, Gould AR, Zupanovic Z, Cunningham AA and others (2000) Comparative studies of piscine and amphibian iridoviruses. Arch Virol 145:301-331

- Hyatt AD, Williamson M, Coupar BE, Middleton D and others (2002) First identification of a ranavirus from green pythons (Chondropython viridis). J Wildl Dis 38:239-252

> Jancovich JK, Davidson EW, Morado JF, Jacobs BL, Collins JP (1997) Isolation of a lethal virus from the endangered tiger salamander Ambystoma tigrinum stebbinsi. Dis Aquat Org 31:161-167

> Johnson AJ, Pessier AP, Jacobson ER (2007) Experimental transmission and induction of ranaviral disease in western ornate box turtles (Terrapene ornata ornata) and redeared sliders (Trachemys scripta elegans). Vet Pathol 44: 285-297

Johnson AJ, Pessier AP, Wellehan JF, Childress A and others (2008) Ranavirus infection of free-ranging and captive box turtles and tortoises in the United States. J Wildl Dis 44:851-863

Langdon JS, Humphrey JD (1987) Epizootic haematopoietic necrosis, a new viral disease in redfin perch, Perca fluviatilis L., in Australia. J Fish Dis 10:289-297

Langdon JS, Humphrey JD, Williams LM, Hyatt AD, Westbury HA (1986) First virus isolation from Australian fish: an iridovirus-like pathogen from redfin perch, Perca fluviatilis L. J Fish Dis 9:263-268

> Mao J, Green DE, Fellers G, Chinchar G (1999) Molecular characterization of iridoviruses isolated from sympatric amphibians and fish. Virus Res 63:45-52

Marschang RE (2011) Viruses infecting reptiles. Viruses 3: 2087-2126 
Marschang RE, Becher P, Posthaus H, Wild P and others (1999) Isolation and characterization of an iridovirus from Hermann's tortoises (Testudo hermanni). Arch Virol 144: 1909-1922

Meddings JI, Owens L, Burgess G, Ariel E (2014) Revelations in reptilian and avian immunology: a proposed evolutionary selection pressure for truncated immunoglobulin-Y. Int J Immunol Stud 2:29-41

Moody NJG, Owens L (1994) Experimental demonstration of the pathogenicity of a frog virus, Bohle iridovirus, for a fish species, barramundi Lates calcarifer. Dis Aquat Org 18:95-102

OIE (World Organisation for Animal Health) (2015) Aquatic animal health code, 17th edn. Section 8: diseases of amphibians. OIE, Paris

Pearman PB, Garner TW (2005) Susceptibility of Italian agile frog populations to an emerging strain of ranavirus parallels population genetic diversity. Ecol Lett 8:401-408

Pozet F, Morand M, Moussa A, Torhy C, de Kinkelin P (1992) Isolation and preliminary characterization of a pathogenic icosahedral deoxyribovirus from the catfish Ictalurus melas. Dis Aquat Org 14:35-42

Price SJ, Garner TWJ, Nichols RA, Balloux F, Ayres C, MoraCabello de Alba A, Bosch J (2014) Collapse of amphibian communities due to an introduced ranavirus. Curr Biol 24:2586-2591

Reddacliff L, Whittington R (1996) Pathology of epizootic haematopoietic necrosis virus (EHNV) infection in rainbow trout (Oncorhynchus mykiss Walbaum) and redfin perch (Perca fluviatilis L). J Comp Pathol 115:103-115

Riley J, Self JT (1981) A redescription of Waddycephalus teretiusculus (Baird, 1862) Sambon, 1922 and a revision of the taxonomy of the genus Waddycephalus (Sambon, 1922), pentastomid parasites of Asian, Australian and

Editorial responsibility: Alex Hyatt,

Geelong, Victoria, Australia
Indonesian snakes, with descriptions of eight new species. Syst Parasitol 3:243-257

Robert J (2010) Emerging ranaviral infectious diseases and amphibian decline. Diversity 2:314-330

Rojas S, Richards K, Jancovich JK, Davidson EW (2005) Influence of temperature on Ranavirus infection in larval salamanders Ambystoma tigrinum. Dis Aquat Org 63: 95-100

Schloegel LM, Daszak P, Cunningham AA, Speare R, Hill B (2010) Two amphibian diseases, chytridiomycosis and ranaviral disease, are now globally notifiable to the World Organization for Animal Health (OIE): an assessment. Dis Aquat Org 92:101-108

Speare R, Smith JR (1992) An iridovirus-like agent isolated from the ornate burrowing frog Limnodynastes ornatus in northern Australia. Dis Aquat Org 14:51-57

Steiner KA, Whittington RJ, Petersen RK, Hornitzky C, Garnett H (1991) Purification of epizootic haematopoietic necrosis virus and its detection using ELISA. J Virol Methods 33:199-209

Teacher AGF, Cunningham AA, Garner TWJ (2010) Assessing the long-term impact of ranavirus infection in wild common frog populations. Anim Conserv 13:514-522

Weir RP, Moody NJG, Hyatt AD, Crameri S, Voysey R, Pallister J, Jerrett IV (2012) Isolation and characterisation of a novel Bohle-like virus from two frog species in the Darwin rural area, Australia. Dis Aquat Org 99:169-177

> Westhouse RA, Jacobson ER, Harris RK, Winter KR, Homer BL (1996) Respiratory and pharyngo-esophageal iridovirus infection in a gopher tortoise (Gopherus polyphemus). J Wildl Dis 32:682-686

Wolf K, Gravel M and Malsberger RG (1966) Lymphocystis virus: isolation in a centrarchid fish cell line. Science 151: 1004-1005

Submitted: October 13, 2014; Accepted: June 9, 2015 Proofs received from author(s): August 9, 2015 